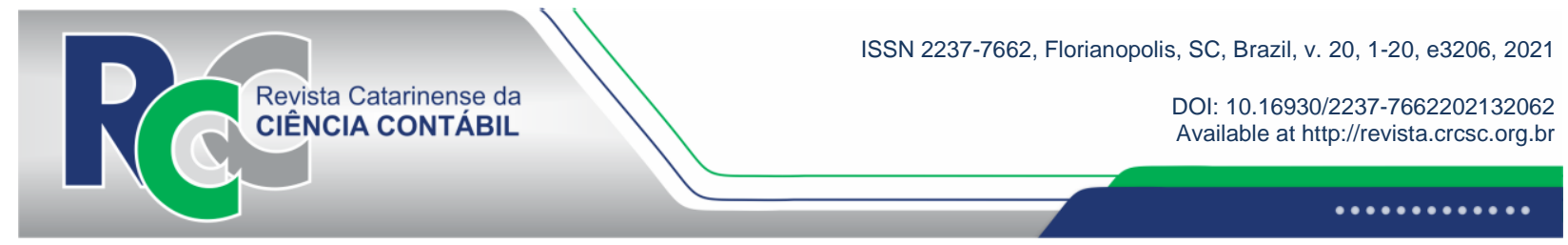

\title{
RELATIONSHIP BETWEEN FREE CASH FLOWS AND CORPORATE GOVERNANCE LEVELS IN THE LIGHT OF AGENCY THEORY
}

\author{
GLAYSSON AGUILAR DE ARAÚJO \\ Federal University of Minas Gerais. Address: Avenida \\ Antônio Carlos, 6,627 | Pampulha | 31270-901 | Belo \\ Horizonte/MG | Brazil. \\ (D) https://orcid.org/0000-0002-7774-2227 \\ glayssonaraujo@yahoo.com.br
}

\section{LARA ALVES CORRÊA}

Federal University of Minas Gerais. Address: Avenida Antônio Carlos, 6,627 | Pampulha | 31270-901 | Belo Horizonte/MG | Brazil.

(1) https://orcid.org/0000-0002-6495-3615

laradbh@hotmail.com

\author{
VALÉRIA GAMA FULLY BRESSAN \\ Federal University of Minas Gerais. Address: Avenida \\ Antônio Carlos, 6,627 | Pampulha | 31270-901 | Belo \\ Horizonte/MG | Brazil. \\ (1) https://orcid.org/0000-0001-6340-9717 \\ vfully@face.ufmg.br
}

\author{
JOÃO ESTEVÃO BARBOSA NETO \\ Federal University of Minas Gerais. Address: Avenida \\ Antônio Carlos, 6,627 | Pampulha | 31270-901 | Belo \\ Horizonte/MG | Brazil. \\ (1) https://orcid.org/0000-0001-5197-2166 \\ joaoestevaobarbosaneto@gmail.com
}

\author{
BRUNA CAMARGOS AVELINO \\ Federal University of Minas Gerais. Address: Avenida \\ Antônio Carlos, 6,627 | Pampulha | 31270-901 | Belo \\ Horizonte/MG | Brazil. \\ (1) https://orcid.org/0000-0001-8958-8725 \\ bcavelino@gmail.com
}

\begin{abstract}
This research analyzes the relationship between free cash flows (FCFs) and the different levels of Corporate Governance present in the Brazilian stock market. To this end, the sample was composed of 212 Brazilian publicly traded companies listed on Brasil, Bolsa, Balcão [B] $]^{3}$, in the period from 2010 to 2018. The methodology consisted of estimating a regression for panel data, using the random effects model, estimating by generalized least square (GLS) and assuming adjustments for autocorrelation and robust standard errors for heteroscedasticity. The results found, for the sample studied, suggest that Corporate Governance levels are positively related to the FCFs. In synergy, when compared to the Traditional level of $[\mathrm{B}]^{3}$, companies listed on the Novo Mercado and Level 2 levels tend to present higher FCF values. In addition, the larger the size of the companies and the higher their return on equity, the higher their FCFs tend to be, just as companies in stages of maturity tend to present lower FCF values. The relevance of this research is based on analyzing, in a stock market subject to imperfections, factors that may affect
\end{abstract}

Edited in Portuguese and English. Original version in Portuguese.

Paper presented at the XX USP International Conference in Acconting, in Sao Paulo, Brazil, July 29-31, 2020.

Received on 9/15/2021. Reviewed on 11/8/2021. Accepted on 11/16/2021 by Prof. Dr. Sérgio Murilo Petri (Editor-in-Chief) and Prof. Dr. Sandro Vieira Soares (Associate Editor). Published on 11/30/2021.

Copyright () 2021 RCCC. All rights reserved. Quoting parts of papers without prior authorization is allowed, as long as the source is identified. 
decisions about the level of cash maintenance of companies, more specifically by evaluating how Corporate Governance mechanisms relate to the theory of FCFs, in a context of potential conflict of interest.

Keywords: Free cash flows. Agency theory. Corporate Governance.

\section{INTRODUCTION}

In the context of the modern business environment, corporations have undergone significant changes, as the corporate structure of companies, previously concentrated, is now pulverized in several shareholders. And management, initially exercised by the capital holders, has been delegated to others, who manage the capital invested by shareholders (Martin, Santos \& Dias Filho, 2004). In this scenario, the foundations of the Agency Theory stand out, in which Jensen and Meckling (1976, p. 308) conceptualize "an agency relationship as a contract under which one or more (chief) persons employ another person (agent) to perform a service on their behalf that entails entrusting the agent with decision-making power". Specifically, the Brazilian stock market is characterized by a high shareholder concentration, and this fact is a potential element of conflicts between agents (Machado \& Galdi, 2021).

Corporate managers are the shareholders' agents, which may cause a relationship full of conflicting interests between shareholders and managers, and the latter may act aiming at their personal interests to take advantage in the management of companies. Under this view, one of the tools that can be used by managers is the Free Cash Flow (FCF), considered as the set of available funds, after financing all projects with positive net present value, updated at the opportunity cost of capital (Jensen, 1986).

Agents use the FCF in ways that diverge from the interests of shareholders, such as investing in dubious projects, consuming unnecessary bonuses, and managing results for selfpromotion (Jensen, 1986). Nevertheless, the FCF, if managed efficiently, can be seen as an important contributing factor to the persistence of good results and, therefore, has drawn the attention of researchers (Wang, 2010).

Ferreira and Vilela (2004) contextualize the following variables as determinants of cash flow: i) set of investment opportunities: it is expected that managers of companies with few investment opportunities retain more resources to invest in growth projects, even if the net present value of these projects is negative, which can cause the destruction of shareholder value; ii) leverage: less leveraged companies are less exposed to monitoring, which allows for greater managerial discretion; and iii) size: there is greater shareholder dispersion in larger companies, which allows managers to have greater implicit powers.

Given this context, Corporate Governance mechanisms were created in order to mitigate losses arising from conflicts of interest between the agent and the chief. It is assumed that, through the adoption of good Corporate Governance practices, the shareholders' resources are efficiently employed in the mission, with a view to achieving the organization's objectives and goals, as well as maximizing the expected returns (Arruda, Madruga \& Freitas Junior, 2008).

For Jensen (1986), companies with few Corporate Governance mechanisms invest their excess cash inefficiently; alternatively, he proposes that excess cash simply reduces pressures on management to control costs, improve margins, closely monitor employees and operations, and generally increase profits. Therefore, it is assumed that poorly managed firms dissipate cash faster than well-governed firms, operating in ways that reduce the enterprise's accounting returns.

Research (Dittmar \& Mahrt-Smith, 2007; McKnight \& Weir, 2009; Dylewski, 2010; Chi \& Lee, 2010 e Wang, 2010) has evaluated the ability of Corporate Governance mechanisms in 
limiting problems arising from FCF, based on Jensen's (1986) hypothesis that Corporate Governance would reduce FCF. That is, firms with higher levels of Corporate Governance would exhibit lower FCF. Jensen (1986) argues that the presence of FCF can lead to managerial waste and inefficiency and, therefore, the holders of capital implement control mechanisms to ensure their interests.

Some of these studies presented results that corroborated Jensen's (1986) hypotheses. Dittmar and Mahrt-Smith (2007), for example, found evidence of the influence of Corporate Governance on cash surpluses. Chi and Lee (2010) found evidence that Corporate Governance affects firm value differently, depending on whether the enterprise has high or low FCF. Other studies, on the other hand, contradict the hypotheses proposed by Jensen (1986). Wang (2010) found that agency costs are negatively associated with firm performance, while FCF is positively related. McKnight and Weir (2009) elucidated that changes in board structures have no impact on agency costs and that having a director nominating committee, which in turn uses meritocracy criteria, increases rather than reduces agency costs. In turn, Dylewski (2010) found results that indicate that companies with a higher level of Corporate Governance have higher levels of cash flow than others.

Papers such as those by Li and Song (2018), Gupta, Mahakud and Verma (2021) and Sprenger and Lazarevab (2021) have highlighted the investment-cash flow sensitivity. Li and Song (2018) specifically tested the effects of anti-takeover protection on investment-cash flow sensitivity, and found that such sensitivity is higher when managers are insulated from takeovers/acquisitions. They also found that the effects of anti-takeover laws on investment sensitivity to cash flow are greater when the firms' accounting information environment is inadequate and when firms have severe agency problems, which are measured by excess free cash flow. Gupta et al. (2021) found that the manager's financial and technical education affects the sensitivity of investment to cash flow for Indian firms, and Sprenger and Lazarevab (2021) found, in a sample of unlisted Russian firms, that better shareholder protection decreases the sensitivity of investment to cash flow.

Given this lack of consolidated understanding, the study and analysis of the relationship between FCFs and Corporate Governance levels can contribute to a better understanding of the dynamics of organizational structures in the Brazilian capital market, in addition to providing subsidies for investment decision-making by participants in this market. Consequently, the question that guides this research can be transcribed as follows: What is the relationship between the free cash flows of organizations and the different levels of Corporate Governance present in the Brazilian stock market?

Thus, the purpose of this study was to analyze the relationship between FCFs and the different levels of Corporate Governance present in the Brazilian stock market, in the period from 2010 to 2018.

The justification for this work is based on the relevance of analyzing, in a stock market subject to imperfections, factors that may affect decisions about the level of cash maintenance of companies, more specifically when evaluating how the mechanisms of Corporate Governance relate to the theory of FCFs, in a context of potential conflict of interest. In this sense, the research brings important results that become useful information to assist the decision-making process of the various stakeholders, which in turn are represented by shareholders, investors, companies, customers and suppliers.

Thus, it contributes to subsidize, with empirical findings, the decision-making process, in addition to encouraging this type of discussion for further research. It is also noteworthy that, by investigating the Brazilian market, marked by a characteristic shareholder concentration, the study gains distinction in relation to previous works, which brings an originality to the domestic scenario. Moreover, this study also differs from previous ones by exploring how the different 
levels of Corporate Governance, differentiated by the listing segments of $[\mathrm{B}]^{3}$, may be related to the FCFs of the organizations.

\section{LITERATURE REVIEW}

\subsection{Free Cash Flow Theory}

As Lerner (2019) points out, it is interesting for shareholders to know how much resources are available to them in the future, so the FCF model exists. Thus, Modigliani and Miller (1958) argue that investment decisions are based on the organizations' FCF, and in its absence, investments will be financed with debt or equity. A company can invest more when cash flow is high because internal funds can be less expensive than external funds, and managers can spend more (Yeo, 2018). In turn, Keynes (1936) highlights that organizations maintain excess cash reserves in preparation to maintain optimal investment levels during negative liquidity periods, termed as the precautionary motive to maintain cash.

Insufficient or excess investments can affect the value of a company. It is known that the value of an enterprise encompasses several components, such as real estate, rights, equipment, brands and cash. Of these components, only cash can be used freely by managers, referred to as FCF. Efficient use or investment of assets will increase the value of the company, while inefficient use of assets will decrease the value of the company (Yeo, 2018).

According to Jensen (1986), the Free Cash Flow Theory addresses the transactions made by managers who reduce free cash by making investments that must have positive net present value relative to the organization's cost of capital. Moreover, the author points out that management has the potential to waste the positive FCF by investing in projects that are not profitable and have low returns for the organizations.

The agency theory, according to Ferreira, Ferreira, Lamounier and Avelar (2021), provides a framework for the FCF Theory, which, at its base, addresses the conflict of interest between managers and shareholders regarding the discretionary use of the firm's resources for their own benefit. Thus, Lang, Stulz and Walkling (1991) clarify that, according to the theory of FCFs, in companies with few investment alternatives, agency costs stand out and, therefore, managers tend to invest in alternatives that have a negative net present value, which does not lead to an increase in the value of the company.

Along the same line, Lerner and Victor (2020) reinforce that if there are agency costs in a given firm, there are residual losses, and the company would be failing to increase its economic performance. Thus, if there are FCFs used inefficiently, consequently, there are agency costs, and the economic performance tends to decrease. Measuring what would be a normal or healthy FCF, as well as an excessive FCF, is a challenge, since what may be excessive for one company may not be for another, given certain particularities such as size, debt, industry (Lerner \& Victor, 2020) or even levels of corporate governance.

\subsection{Corporate Governance in the Context of Agency Theory}

Given the agency relationship, defined by Jensen and Meckling (1976) as a contract under which the chief employs the agent to perform on his/her behalf activities that delegate some decision-making power to the latter, an environment fraught with disruption is then generated. That is, this separation between the shareholder and the manager develops a complex environment, conducive to the emergence of the information asymmetry problem, in which the agent (manager) has an informational advantage over the chief (shareholder), being able to act according to his/her own interests to the detriment of the welfare of the shareholder (MachoStadler \& Pérez-Castrillo, 2001). 
Jensen and Meckling (1976) point out that when both parties, agent and chief, are utility maximizers, there are motivations to believe that the agent will not always make decisions in favor of the chief's interests. Nevertheless, the chief may adopt incentive mechanisms for the agent in order to minimize irregular activities of the latter, which will bring him/her monitoring costs. In synergy, Lambright (2009), when contextualizing the assumptions of the Agency Theory, highlights that the unfolding of agency problems can be understood through the concepts of adverse selection and moral hazard.

Adverse selection occurs when their market station cannot differentiate the type or quality of the other party's goods, which derives from the existence of privileged information for one of the parties before the contract is executed. Moral hazard, on the other hand, occurs when the agent's action is unverifiable, not allowing the chief to determine the agent's actions (Klann, Gomes, Greuel \& Bezerra, 2014).

Based on these assumptions, Jensen and Meckling (1976) argue that it is impossible for either the chief or the agent to maintain the agency relationship without costs, with a view to ensuring that the agent will always make optimal level decisions considering the chief's point of view. In order to minimize such conflicts, companies adopt the practice of mechanisms that can monitor the agents through Corporate Governance.

Thus, the "development of corporate governance has been marked by the search for minimizing conflicts between shareholders and executives" (Oliveira \& Fontes Filho, 2021, p. 511). Shleifer and Vishny (1997) elucidate that Corporate Governance deals with the ways in which resource providers ensure that they will obtain for themselves the return on their investment. In a more normative context, the Brazilian Institute of Corporate Governance (IBGC) elucidates that "Corporate Governance is the system by which companies and other organizations are managed, monitored and encouraged, involving the relationships between partners, board of directors, management, supervisory and control bodies, and other stakeholders" (IBGC, 2019).

Also according to IBGC (2019), good Corporate Governance practices tend to converge principles into objective recommendations, in order to align interests and with a view to optimizing the company's value. Regarding its principles, Lodi (2000) presents them as follows: i) fairness: sense of justice and equity towards minority shareholders against transgressions by majority shareholders and managers; ii) disclosure: called transparency, comprises accurate data, accounting records beyond doubt and reports delivered within the agreed deadlines; iii) accountability: called provision of accounts, it refers to the rendering of accounts by those who make business decisions; and iv) compliance: fulfillment and obedience to the laws of the country.

According to $[\mathrm{B}]^{3}$ (2019), in Brazil, the special listing segments are characterized in: a) Novo Mercado: launched in 2000, Novo Mercado has established since its creation a highly differentiated Corporate Governance standard; b) Level 1: companies listed in the Level 1 segment must adopt practices that favor transparency and access to information by investors. To this end, they disclose information in addition to that required by law, such as an annual calendar of corporate events; c) Level 2: similar to Novo Mercado, but with some exceptions. Listed companies have the right to maintain preferred shares; and d) Bovespa Mais: designed for companies that wish to access the market gradually, this segment aims to foster the growth of small and medium-sized companies via the capital market.

Corporate governance mechanisms, as highlighted by Hedlund et al. (2021), are configured as an important strategic tool in organizations, contributing to the reduction of agency conflicts and the development of strong relationships among all stakeholders in the firm. Thus, effective governance practices can help control the dilemma that exists between managers and shareholders (Sehrawat et al., 2019). With the mechanisms of accountability, transparency, and 
oversight, best corporate governance practices can increase shareholders' communication and trust in managers, which means that understanding these mechanisms can help reduce the agency problem between owners and managers (Huu Nguyen, Thuy Doan \& Ha Nguyen, 2020).

In this way, companies with higher Corporate Governance quality indexes are expected to offer a more consistent protection to their investors, through a professional, responsible, transparent and fair management for shareholders, executives and third parties, taking into account that good Corporate Governance practices allow minimizing the impacts of managers' opportunistic behaviors (Silva, Caixe \& Krauter, 2019). In completeness, Dylewski (2010) highlights the hypothesis that a management not committed to good Corporate Governance practices would present higher levels of cash flow, being this an expected relationship.

\subsection{Free Cash Flows and Corporate Governance}

A number of studies have been conducted on the topics of agency theory, cash flow theory and Corporate Governance and their interrelationships. Most of the research aims to raise evidence on the relationship of elements of Corporate Governance. This subsection presents a summary of the results of some academic research already conducted focusing on FCF theory and Corporate Governance.

Dittmar and Mahrt-Smith (2007) investigated whether Corporate Governance affected firm value by comparing the value and use of cash reserves in well managed and poorly managed firms. To do this, the authors performed ordinary least squares (OLS) regression estimation with robust standard errors of all publicly traded firms in the United States over the period from 1990 to 2003. They found evidence that high levels of Corporate Governance double cash surpluses; on the other hand, firms with poor Corporate Governance practices dissipate cash quickly, causing operating performance to decline significantly. Thus, governance has a greater influence on the use, rather than the accumulation, of cash reserves. This implies that governance affects operating and investment decisions (how to use cash) more than financing decisions related to cash policy (how much cash to accumulate).

McKnight and Weir (2009) examined the relationship between Corporate Governance and agency costs as measured by the ratio of sales to total assets, the interaction of free cash flows and growth prospects, and the number of acquisitions. The sample comprised publicly listed companies in the UK over the period 1996 to 2000. The empirical results highlighted that increased board ownership and debt reduce agency costs. However, changes in Board structures impact agency costs; and having a nominating committee increases rather than reduces agency costs.

Dylewski (2010) studied the determinants of net asset levels of publicly traded companies in Brazil, Argentina, Chile, Mexico, and Peru over the period 1995 to 2009, given the backdrop of increasing trends in net asset accumulation. The author found evidence that firms with greater growth opportunities, larger size, higher level of dividend payouts, and higher profitability levels accumulate more cash in most of the analyzed countries. Similarly, companies with higher levels of investment in fixed assets, higher cash generation, higher cash flow volatility, higher leverage, and higher working capital levels have lower levels of net asset accumulation. Furthermore, it was also found that companies with higher levels of Corporate Governance have more cash, which is contrary to the hypothesis that a more committed management maintains a lower level of liquidity.

Chi and Lee (2010) examined the relationship between Corporate Governance and firm value conditional on the level of FCF available to directors. They analyzed North American firms in the years 1990-2004, employing the Fama and MacBeth (1973) regression method, which involves running annual regressions of firm value on simultaneous governance variables, 
averaging the time series of the coefficient estimates, and inferring statistical significance based on the standard errors of the time series. The authors found evidence that Corporate Governance affects firm value differently, depending on whether the firm has high or low FCF. Specifically, firm value increases with better governance levels among high FCF entities, while the effect of governance is smaller or insignificant among low FCF firms.

In turn, Wang (2010) investigated how FCF was associated with agency costs and would influence firm performance. To test the hypotheses, data were based on all publicly listed firms on the Taiwan Stock Exchange from 2002 to 2007. The author identified that agency costs are negatively and significantly associated with firm performance, while FCF is positively and significantly related to firm performance. The former result supports agency theory, while the latter is inconsistent with the FCF hypothesis.

Silva, Caixe and Krauter (2019) investigated the sensitivity of investment to cash flow for Brazilian firms listed on $[\mathrm{B}]^{3}$ with different corporate governance levels, over the period from 2006 to 2015. The results evidenced that the quality of corporate governance influenced the investment-cash flow sensitivity, so that this relationship was negative and significant only for firms with the worst governance. This finding can be understood as an indication that such companies seek to increase their cash reserves and reduce investments for reasons related to financial constraints and/or agency problems.

Zhang (2020) sought to relate Corporate Governance to agency costs of Free Cash Flows in US domestic procurement. The findings indicated that the quality of Corporate Governance indirectly affects merger outcomes by mitigating the agency problem associated with the retention, rather than use, of free cash flows. Waly, Sasongko and Achyani (2021), meanwhile, analyzed the effect of free cash flow, Corporate Risk Management disclosure, and sustainability reporting on the value of companies listed on the Jakarta Islamic Index over the period 20152019, with good corporate governance as a moderating variable. The results evidenced that none of the three variables analyzed - Free Cash Flow, Corporate Risk Management disclosure, and sustainability report disclosure - had an effect on the value of the firms in the sample.

Sprenger and Lazarevab (2021) investigated, in a sample of unlisted Russian companies, how Corporate Governance affected financing constraints, as measured by the sensitivity of investment to cash flow. The main result found was that better shareholder protection decreases the sensitivity of investment to cash flow, especially in firms with an external controller. In contrast, this effect was not found for transparency, which may be partially explained by the threat of hostile takeovers.

Based on the studies presented, the relationship between FCF and Corporate Governance has been addressed in several contexts. Dittmar and Mahrt-Smith (2007) and Chi and Lee (2010) focused on the relationship of Corporate Governance affecting firm value, finding evidence, respectively, that high levels of governance double cash surpluses and that firm value increases with better levels of governance. Dylewski (2010), meanwhile, found findings suggesting that the higher the level of Corporate Governance, the higher the level of net assets of firms tends to be. Finally, Wang (2010) and McKnight and Weir (2009) focused on the issue of agency cost, with findings, respectively, that agency costs relate negatively to firm performance and that Board structural changes add little effect on agency costs.

\section{METHODOLOGY}

\subsection{Research Classification, Population, Sample and Data Collection}

As for the research classification, this study adopted the categorization presented in Raupp and Beuren (2008), being classified as descriptive and explanatory, documentary and quantitative. 
The population of this study encompassed all Brazilian publicly traded companies listed on $[\mathrm{B}]^{3}$ in the period from 2010 to 2018 , making a total of nine years. The initial year of the chosen period is justified due to the convergence to international accounting standards, which began to be effective in Brazil with the publication of Laws No. 11,638/07 and 11,941/2009, in addition to the Technical Pronouncements issued by the Accounting Pronouncements Committee (CPC) (Gelbecke, Santos, Iudicíbus \& Martins, 2018). Thus, as of the year 2010, the financial statements published by entities began to follow an international standard, following standardization and comparability criteria. In turn, the final year of 2018 is justified by virtue of being the last year with annual data closed and made available when this research was conducted.

The data collection process was carried out through the Economática® software. Thus, it became possible to access all the financial statements of Brazilian companies listed on $[\mathrm{B}]^{3}$. Therefore, companies characterized as financial institutions were excluded from the initial population, because they have particularities with accounting statements and charts of accounts that are different from other enterprises.

Another criterion adopted was to exclude from the initial population all enterprises that did not present information on net revenues in all years. The choice for this addressing is justified by considering that companies that did not present such information in any of the years of analysis have not developed their operations in that period. This criterion was also adopted by Avelar, Cunha, Boina and Souza (2015), who justified that net revenue represents the revenues arising from the company's operational activities.

It is worth mentioning that the sampling process is not probabilistic, since it is based on a naturally restricted universe, excluding enterprises that did not present sufficient data, which means that the results cannot be generalized to the entire population of Brazilian companies. The final sample of this research was composed of 212 companies, with the largest concentration being in the Cyclical Consumption, Industrial Goods, and Public Utilities sectors, which represent $30 \%, 20 \%$, and $20 \%$ of the total sample, respectively. Furthermore, the study sample was composed in an unbalanced way.

\subsection{Variables Analyzed}

The dependent variable analyzed in this study refers to FCFs, represented by the code FCL. Equation 1 elucidates its calculation methodology:

$$
F C L=N O P A T+D E P-C A P E X-I N V C A P
$$

Where:

FCL $=$ Free Cash Flow

NOPAT $=$ Net Operating Profits Less Adjusted Tax

$\mathrm{DEP}=$ Depreciation

CAPEX = Capital Expenditure

INVCAP $=$ Working Capital Investment

Subsequently, in order to minimize the variability of the observations found in this variable, given the diversity of the sample, the natural logarithm was applied to the value presented.

The independent variables of the proposed model, incorporated with the purpose of establishing relations with the dependent variable, were as follows: i) Corporate Governance Levels, which, in the final sample, were represented by the levels: Traditional, Novo Mercado, 
Level 1 and Level 2; ii) company size, represented by total assets; iii) profitability, with the adopted proxy being ROE (Return on Equity); and iv) Growth rate, measured by the variation in net revenue. It is worth mentioning that the inclusion of variables was originated in the theory of FCFs presented by Jensen (1986), and that the aim was to find other authors in the literature who have already researched these variables, in order to corroborate the relationships expected in this study. Table 1 lists the variables mentioned above.

Table 1

\section{Explanatory variables of the model}

\begin{tabular}{|c|c|c|c|}
\hline Variable & Proxy & Source & Expected Relationship \\
\hline $\begin{array}{l}\text { Novo Mercado } \\
\text { Governance Level } \\
\text { (NOVMER) }\end{array}$ & $\begin{array}{c}\text { Dichotomous variable, assumes value } 1 \text { if } \\
\text { belonging to the Novo Mercado segment and } 0 \\
\text { otherwise }\end{array}$ & $\begin{array}{l}\text { Jensen }(1986) ; \\
\text { Dylewski } \\
(2010) \text {. }\end{array}$ & - \\
\hline $\begin{array}{l}\text { Governance Level } 1 \\
\text { (NIV1) }\end{array}$ & $\begin{array}{l}\text { Dichotomous variable, assumes value } 1 \text { if } \\
\text { belonging to the Level } 1 \text { segment and } 0 \text { otherwise }\end{array}$ & $\begin{array}{l}\text { Jensen }(1986) \\
\text { Dylewski } \\
(2010) \text {. }\end{array}$ & - \\
\hline $\begin{array}{l}\text { Governance Level } 2 \\
\text { (NIV2) }\end{array}$ & $\begin{array}{l}\text { Dichotomous variable, assumes value } 1 \text { if } \\
\text { belonging to the Level } 2 \text { segment and } 0 \text { otherwise }\end{array}$ & $\begin{array}{l}\text { Jensen }(1986) \\
\text { Dylewski } \\
\text { (2010). }\end{array}$ & - \\
\hline $\begin{array}{l}\text { Firm Size } \\
\text { (TAM) }\end{array}$ & Ln of Total Assets & Jensen (1986). & + \\
\hline $\begin{array}{l}\text { Return on Equity } \\
\text { (ROE) }\end{array}$ & $\frac{\text { Net Income }}{\text { Average Net Equity }}$ & Jensen (1986). & - \\
\hline $\begin{array}{l}\text { Growth Rate } \\
\text { (TAXCRESC) }\end{array}$ & $\frac{\left.(\text { Net Revenue }) t_{-} \text {Net Revenue }\right) t_{-1}}{(\text { Net Revenue })_{t_{-1}}}$ & $\begin{array}{l}\text { Jensen e } \\
\text { Meckling } \\
\quad(1976) ; \\
\text { Jensen (1986). }\end{array}$ & - \\
\hline
\end{tabular}

Source: Prepared by the authors

As detailed in Table 1, the Corporate Governance levels were represented by dummies variables, that is, variables of a dichotomous nature, which assume value 0 in the absence of the attribute considered by the variable, and value 1 in the presence of the attribute (Gujarati \& Porter, 2011). The governance levels present were: Traditional, Novo Mercado, Level 1 and Level 2. Thus, the Traditional level was adopted as a control, which allowed the inclusion of three dummies variables.

The first dummy was represented by the code NOVMER, which assumes value 1 if the company belongs to the Novo Mercado level and 0 otherwise. The second dummy, code NIV1, represented Level 1, with companies belonging to the respective level assuming value 1 and 0 otherwise. The third and last dummy was coded NIV2 and was represented by Level 2, which, in turn, assumed value 1 if the company belongs to this level, and 0 otherwise.

The inclusion of variables related to Corporate Governance is based on the study by Jensen (1986), who elucidates that companies with excess cash incur agency costs, since agents (managers) choose not to pay dividends to shareholders, even in the absence of profitable investment projects. Based on this premise, the adoption of Corporate Governance practices could minimize this conflict between agent versus chief. Dylewski (2010) addressed the level of governance of companies participating in the BMF\&Bovespa's Corporate Governance Stock Index (IGC), finding a negative relationship with the liquidity variable of firms, being represented by liquid assets. In synergy, the relationship expected in this study is negative, that is, companies with good Corporate Governance practices would tend to present lower FCFs. 
The other independent variables were quantitative in nature. Thus, the company size variable was represented by the code TAM and was obtained by calculating the natural logarithm of its total assets. The use of this variable is based on the work of Jensen (1986), who highlights that companies considered to be mature, because they have already made all the necessary investments for their growth in the past, tend to present a higher value of assets. Thus, a positive relationship is expected with the dependent variable.

In completeness, to represent the independent variable Profitability, the return on equity, also known as ROE, was adopted as a proxy, and this is the variable description in the model. Based on Jensen (1986), who infers that managers choose to invest in unprofitable projects to the detriment of remunerating shareholders, it is expected that the lower the profitability, the lower the FCF.

Finally, the last independent variable was the Growth Rate, represented by the code TAXCRESC. The calculation of this variable was obtained by the variation in net revenue in relation to the previous period. The theory presented by Jensen (1986) contextualizes that companies in the growth phase, which have not yet reached a stage of maturity, tend to present a lower volume of FCFs. From this point of view, a negative relationship is expected with the dependent variable. Moreover, Jensen and Meckling (1976) corroborate that companies that are more likely to generate higher FCFs are represented by companies located in more mature industries.

\subsection{Econometric Model and Data Processing}

Since this research deals with data that vary in time and space, a panel of observations is constituted. In this respect, Gujarati and Porter (2011) point out that, in panel data, the same cross-sectional unit (a household, a firm, a state) is followed over time. Thus, the econometric model proposed in this study is detailed in Equation 2.

$$
\begin{aligned}
& F C L_{i t}=\beta_{0}+\beta_{1} \times N O V M E R_{i t}+\beta_{2} \times N I V 1_{i t}+\beta_{3} \times N I V 2_{i t}+\beta_{4} \times T A M_{i t}+\beta_{5} \times R O E_{i t}+ \\
& \beta_{6} \times \text { TAXCRESC }_{i t}+c i+\varepsilon_{i t}
\end{aligned}
$$

Where:

$\mathrm{FCL}_{\mathrm{it}}=$ Free Cash Flows;

$\beta_{0}=$ Intercept of the model (constant);

$\beta_{1}, \beta_{2}, \beta_{3}, \beta_{4}, \beta_{5}$ e $\beta_{6}=$ Angular coefficients of the model;

NOVMER it $=$ Novo Mercado Governance Level. Assumes value 1 when the company belongs to Novo Mercado and 0 otherwise;

NIV $1_{\text {it }}=$ Governance Level 1 . Takes value 1 when the company belongs to Level 1 and 0 otherwise;

NIV $2_{\text {it }}=$ Governance Level 2. Takes value 1 when the company belongs to Level 2 and 0 otherwise;

$\mathrm{TAM}_{\mathrm{it}}=$ Firm size;

$\mathrm{ROE}_{\mathrm{it}}=$ Return on Equity;

TAXCRESC $_{\text {it }}=$ Growth rate;

$c_{i}=$ unobservable individual specific effect, which differs across units, and is time invariant;

$\varepsilon_{\mathrm{it}}=$ Usual error of the regression.

Panel data models can be presented in three main groups: i) MQO Model for pooled data; ii) Fixed Effects Model (MEF); and iii) Random Effects Model (MEA). In the pooled model, a regression is estimated disregarding the cross-section and time series nature, working with 
stacked data. In MEF, the intercept of the regression model may differ across individuals, due to the fact that each individual, or cross-sectional unit, may have their own special characteristics. MEA, on the other hand, assumes that the intercept values are drawn randomly from a much larger population with a constant mean value (Gujarati \& Porter, 2011).

All statistical tests were performed to reach the final model to be presented by the study, with the definition of the approach that best meets the characteristics of the sample. The tests performed to choose the model were adopted as outlined in the literature, such as the Chow test, the Breusch-Pagan (BP) test and the Hausman test (Baltagi, 2005; Gujarati \& Porter, 2011). Furthermore, it is worth mentioning that all assumptions for model validation were observed, such as: absence of multicollinearity, correct model specification, normality of residuals, absence of serial autocorrelation, and homoscedastic residuals. Data were treated and tabulated using STATA 14.0® software and Microsoft Excel® (MS-Excel) 2019 software.

\section{ANALYSIS OF RESULTS}

\subsection{Descriptive Statistics}

After defining the final sample, we sought to present the descriptive statistics about the variables analyzed in this study. Regarding the listing segments in $[\mathrm{B}]^{3}$, there was a predominance of companies adhering to Novo Mercado, followed by companies belonging to the Traditional segments, Level 1 and Level 2, being, respectively, represented by 45\%, 39\%, 9\% and $6 \%$ of the total sample. Figure 1, meanwhile, presents the FCF history for the period from 2010 to 2018 for the Traditional, Level 1, Level 2, and Novo Mercado Corporate Governance levels.

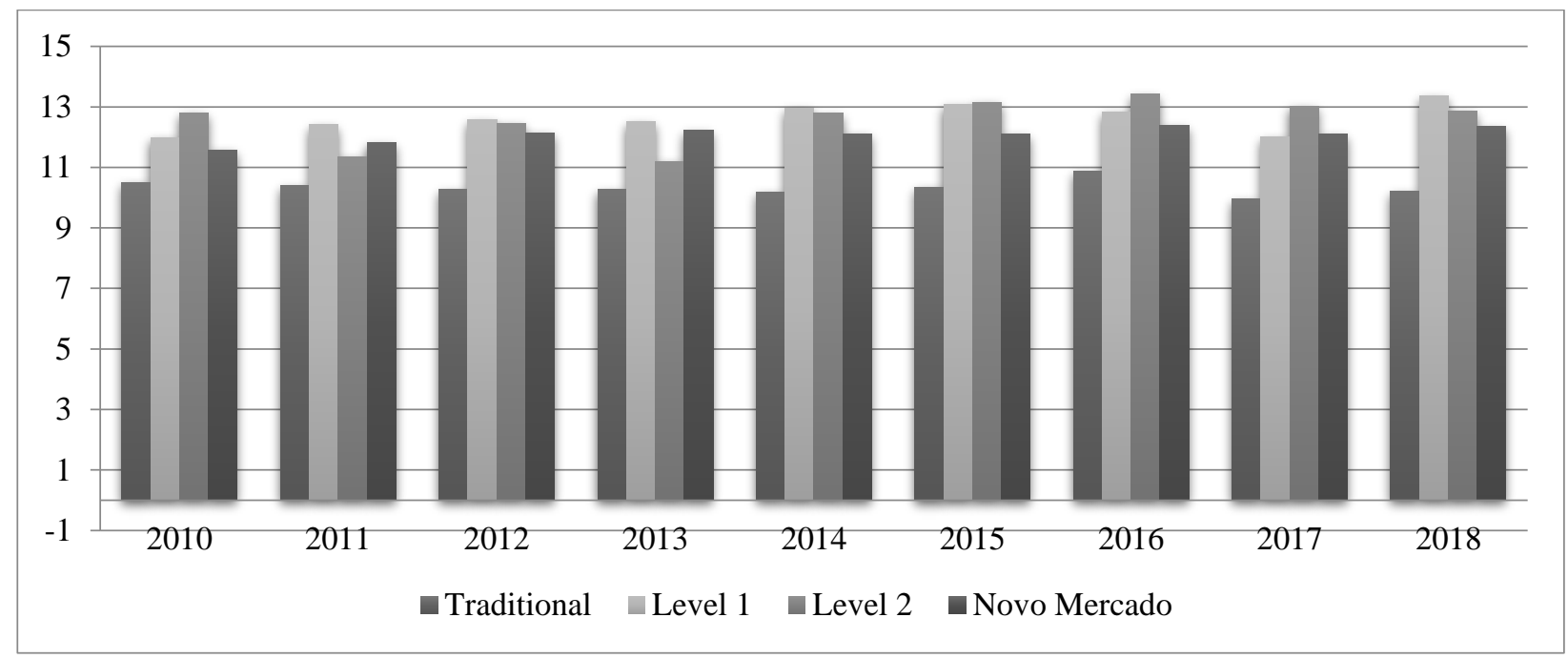

Figure 1. FCF by Corporate Governance Level

Source: Research data.

Based on the data presented in Figure 1, we identify, as a characteristic of the Brazilian public companies in the sample, the fact that they present lower FCFs in companies that do not fit into any of the Corporate Governance levels and higher FCFs for Levels 1 and 2, with a small reduction in the Novo Mercado level. This shows that there is a tendency for FCFs to grow until the penultimate level of Corporate Governance and a slight decline in the last level. In this study, based on Jensen's (1986) hypothesis that Corporate Governance would reduce the FCF, it was 
expected that companies that did not fit into any of the Governance levels would present the highest FCFs, which was not actually the case. However, more assertive results can only be observed after estimating the regression model, which is the subject of the following topic.

Table 2 presents the descriptive statistics of the data, showing the means, standard deviations, minimum and maximum values, coefficient of variation, degree of asymmetry and quartiles of the quantitative variables used in the study.

Table 2

Descriptive Statistics of Variables for Sample based on November 2019

\begin{tabular}{l|c|c|c|c|c|c|c}
\hline Description & FCF & NOVMER & NIV1 & NIV2 & TAM & ROE & TAXCRESC \\
\hline Notes & 1105 & 1908 & 1908 & 1908 & 1908 & 1707 & 1899 \\
\hline Minimum & 0 & 0 & 0 & 0 & 8.69 & -5451.53 & -1.33 \\
\hline Maximum & 18.09 & 1 & 1 & 1 & 20.62 & 7500 & 109.77 \\
\hline Mean & 11.56 & 0.453 & 0.094 & 0.061 & 14.742 & 0.082 & 0.219 \\
\hline Standard Deviation & 2.16 & 0.498 & 0.292 & 0.24 & 1.839 & 245.402 & 2.834 \\
\hline Coefficient of Variation & 0.19 & 1.1 & 3.099 & 3.914 & 0.125 & 3004.6 & 12.916 \\
\hline Asymmetry & -0.65 & 0.19 & 2.776 & 3.657 & -0.09 & 10.048 & 33.154 \\
\hline Q25 & 10.27 & 0 & 0 & 0 & 13.525 & 0.35 & -0.03 \\
\hline Q50 & 11.79 & 0 & 0 & 0 & 14.81 & 8.53 & 0.08 \\
\hline Q75 & 12.98 & 1 & 0 & 0 & 16 & 16.92 & 0.19 \\
\hline
\end{tabular}

Source: Research data.

Based on the data in Table 2, it can be seen that the study variables have a certain linearity and, by analyzing the standard deviations, maximum and minimum values, it can be inferred that the data are organized around the mean homogeneously. The only variable that escapes a little from this configuration is the growth rate, which has a mean of 0.219 , a minimum value of -1.33 and a maximum of 109.77 , showing that there is a certain concentration of negative values below the mean.

\subsection{Inferential Statistics}

In order to identify the most appropriate model for the presentation and discussion of the results, statistical tests were performed to validate the final model. The significance level adopted in this study was 5\%. Table 3 presents a summary of the results of the applied tests.

Table 3

Model validation tests with data based on November 2019

\begin{tabular}{lcccc} 
Criterion analyzed & Test used & VIF & P-Value & Result \\
\hline Absence of Multicollinearity & $\begin{array}{c}\text { Variance inflation factor } \\
(\text { VIF) test }\end{array}$ & 1.24 & - & Absence of Multicollinearity \\
Adequate functional form & RESET test & - & 0.1209 & Adequate functional form. \\
Pooled model versus MEF & Chow's test & - & 0.0000 & Preferable MEF \\
Pooled model versus MEA & Breusch-Pagan test & - & 0.0000 & Preferable MEA \\
MEA versus MEF & Hausman test & - & 0.6697 & Preferable MEA
\end{tabular}




\begin{tabular}{lcccc}
\hline Criterion analyzed & Test used & VIF & P-Value & Result \\
\hline $\begin{array}{l}\text { Absence of Autocorrelation } \\
\begin{array}{l}\text { Absence of } \\
\text { Heteroscedasticity }\end{array}\end{array}$ & Wooldridge test & - & 0.0084 & Presence of autocorrelation \\
\hline Lource: Likelihood-Ratio Test & - & 0.0000 & Presence of heteroscedasticity \\
\hline
\end{tabular}

Source: Research data.

The pooled model was initially estimated and, from the results, the assumption of absence of multicollinearity was evaluated, as well as whether the model had adequacy of the functional form. The variance inflation test (VIF) was used to check whether the model indicated the presence of a strong correlation between the explanatory variables. Fávero, Belfiore, Silva and Chan (2009) elucidate that a VIF above 5 can lead to multicollinearity problems. The joint or individual result did not indicate the presence of multicollinearity, and a mean VIF of 1.24 was found.

Next, we checked whether the model presented an adequate functional form. The performed test was the Ramsey test, called RESET (Regression Specification Error Test). Gujarati and Porter (2011) point out that one advantage of RESET is that it is easy to be applied, since it does not require specifying the alternative model. The null hypothesis of the test indicates that the model has no relevant omitted variables, exhibiting adequate functional form. The result found for the test in question was a p-value of 0.1209 , which does not reject the null hypothesis at the 5\% significance level, indicating the correct specification of the model.

The next step was to estimate the model considering fixed effects. From its estimation, it was possible to examine the result of the Chow Test, in order to evaluate the use of the model with fixed effects versus the pooled model. The result of the p-value was 0.000 , thus rejecting, at a $5 \%$ significance level, the null hypothesis of using the pooled model, with the MEF being preferable.

Next, the model considering random effects (MEA) was estimated, and the Lagrange Multiplier (LM) test, developed by Breusch and Pagan, was applied to evaluate the use of the pooled model versus the MEA. The p-value found was 0.0000 , so the null hypothesis of using the pooled model was rejected and the MEA was preferred.

Given this scenario, the Hausman test was adopted in order to validate the model to be used - MEF or MEA. Johnston and DiNardo (2001) clarify that to perform the Hausman test, two estimators with different properties are deduced in order to consider whether or not the specific unobservable individual effect (ci) and the regressors are correlated. Thus, the null hypothesis points out that if $\mathrm{c}_{\mathrm{i}}$ is not correlated with the explanatory variables, the random effects model should be used. The p-value found was 0.6697 , not rejecting the null hypothesis, so the most suitable model is the MEA.

After defining the random effects model as the most appropriate for this study, we tested, through the Wooldridge test, if it did not present first order autocorrelation, this being the null hypothesis of the test. At the adopted level of 5\% significance, the null hypothesis was rejected, given the p-value of 0.0084 , i.e., the model presented an autocorrelation problem. In this case, Gujarati (2006) suggests that in the presence of autocorrelation, the panel should be estimated by the generalized least squares method. Thus, the model was estimated by the mentioned method, considering the presence of autocorrelation.

In completeness, we verified if the model estimated by generalized least squares presented the heteroscedasticity problem. The Likelihood-Ratio (LR) test presented a p-value of 0.0000 , which makes the null hypothesis of homoscedasticity to be rejected, so the model presented the heteroscedasticity problem. On this scenario, given the presence of autocorrelation 
and heteroscedasticity, the final model was estimated by generalized least squares, assuming the adjustments for autocorrelation and heteroscedasticity. Table 4 presents the results found for the final adjusted model.

Table 4

MEA adjusted for autocorrelation and heteroscedasticity with November 2019 data

\begin{tabular}{|c|c|c|c|c|}
\hline Estimated covariance(s) & 184 & & No. of notes & 980 \\
\hline Estimated autocorrelation(s) & 1 & & No. groups & 184 \\
\hline Estimated coefficients & 7 & & Group note: & 2 \\
\hline Wald $\left(x^{2}\right)$ & 12565.16 & & mean & 5.3261 \\
\hline Prob $>x^{2}$ & 0,0000 & & $\max$ & 9 \\
\hline FCF & Coef. & $\begin{array}{c}\text { Standard } \\
\text { Error }\end{array}$ & $\mathbf{Z}$ & $\mathbf{P}>|\mathbf{Z}|$ \\
\hline NOVMER & 0.1084214 & 0.0347126 & 3.12 & 0.002 \\
\hline NIV1 & -0.0495338 & 0.0710259 & -0.70 & 0.486 \\
\hline NIV2 & 0.44608052 & 0.0735031 & 6.08 & 0.000 \\
\hline TAM & 0.9260518 & 0.0110428 & 83.86 & 0.000 \\
\hline ROE & 0.0004246 & 0.000082 & 5.18 & 0.000 \\
\hline TAXCRESC & -0.243468 & 0.0559229 & -4.35 & 0.000 \\
\hline Constant & -2.013471 & 0.01533721 & -13.13 & 0.000 \\
\hline
\end{tabular}

Source: Research data.

Based on the analysis of the results of the final validated model, by Wald's test, we noticed the rejection of the null hypothesis, that all estimated parameters are statistically equal to zero. With regard to the explanatory variables, to analyze the individual significance of each of them, the result of the p-value of the $\mathrm{Z}$ test was evaluated. We noticed that the only variable that did not show significance at the 5\% level was NIV1, which represents the companies listed in the $[\mathrm{B}]^{3}$ Level 1 segment.

The NOVMERC and NIV2 variables showed statistical significance and indicated a positive relationship with the FCF dependent variable. Such result implies that companies that adopt Corporate Governance levels tend to present higher FCFs, which contradicts the expected result in this study, in a context of mechanisms used to minimize agency conflicts. Dylewski (2010) points out that this relationship may be less applicable in developing countries, since the opportunity cost of keeping resources in financial investments compared to productive investments is lower. Moreover, companies with higher levels of governance may be committed to optimizing their level of leverage, in addition to the possibility of maintaining a level of liquidity "cushion" to face times of crisis.

Studies such as those by Silva et al. (2019) and Sprenger and Lazarevab (2021), which specifically analyze the sensitivity of investment to cash flow, can also assist in understanding the results of this research. According to Silva et al. (2019), one possible explanation for the positive impact of cash flow on investment, tied to corporate governance practices, is that managers would tend to overinvest excess cash flows when pursuing their private benefits, so that better corporate governance practices would also reduce the positive influence of cash flow on investment (Francis, Hasan, Song \& Waisman, 2013).

The empirical results observed by Silva et al. (2019) pointed out that companies with worse governance practices have negative sensitivity of investment to cash flow, a fact that can be attributed to the willingness of these companies to raise their cash reserves for reasons associated with financial constraints and/or agency problems. Sprenger and Lazarevab (2021) 
observed that better shareholder protection, which is associated with Corporate Governance mechanisms, decreases the sensitivity of investment to cash flow.

In this study, whose variable of interest is the amount of FCF, the results contradict Jensen's (1986) hypothesis that Corporate Governance would reduce such flow, based on the fact that the presence of FCF could lead to managerial waste and inefficiency. However, they are in line with Dylewski's (2010) findings that companies with a higher level of Corporate Governance have higher levels of cash flow than others. Thus, a more committed management, with better Corporate Governance practices, does not necessarily maintain a lower level of liquidity.

It is also noteworthy that, contrary to expectations, a significant and negative relationship between the FCF and Level 1 of Corporate Governance was not verified. These results may only be situational, or they can be explained by the fact that in some environments, when the company has high levels of cash liquidity, managers may protect themselves, preferring to keep cash balances and not invest at all, which results in accumulations of excess cash in order to increase the assets in their possession. This can lead to corporate underinvestment, resulting from not investing in profitable projects that create value for the company.

The TAM variable, represented by firm size, showed statistical significance at the $5 \%$ level, culminating in a positive relationship with the FCFs variable. From this perspective, the found result corroborates the relationship expected in the study, being in accordance with Jensen's (1986) theory. In synergy, the ROE variable also presented statistical significance, being validated in the model estimated in this research. Thus, it can be inferred that it has a positive relationship with the FCF dependent variable. This fact implies that the higher the profitability of companies, measured in this study by the proxy return on equity, the greater tends to be the FCF, which contradicts the expected relationship in the study, as based on the theory of Jensen (1986). In this perspective, Wang (2010) highlights that FCFs can provide companies with investment opportunities that generate more value for them, causing a positive impact on their performance.

Finally, the variable TAXCRESC, which represents the growth rate of companies, was significant in the model and showed a negative relationship with the variable FCF. This result allows us to infer that companies still in the growth phase, which have not reached maturity, tend to have a lower FCF, corroborating the evidences of Jensen and Meckling (1976) and Jensen (1986), within a context of agency conflict.

\section{FINAL CONSIDERATIONS}

This research aimed to analyze the relationship between organizations' FCFs and the different levels of Corporate Governance present in the Brazilian stock market. The theory defended by Jensen (1986) argues that the presence of FCFs can lead to waste and managerial inefficiencies and, therefore, the holders of capital implement control mechanisms to guarantee their interests, in order to minimize conflicts of interest present in the agency relationship.

The found results suggest that the governance levels of the Brazilian stock market Novo Mercado and Level 2 show a significant and positive relationship with the FCF. This means that the higher the levels of governance practiced by the organizations, the higher the FCFs they present, when compared to the companies listed in the Traditional segment of $[\mathrm{B}]^{3}$. This result refutes the assumption that the essence of Corporate Governance is to minimize the impacts of agency conflicts, but reinforces the results presented by Dylewski (2010).

Regarding the other independent variables included in the model estimated in this study, the return on equity also showed statistical and positive significance with the FCF, which implies that the higher the profitability of companies, measured in this work by the proxy return on 
equity, the greater tends to be their FCF, which contradicts the expected relationship in the study, as based on the theory of Jensen (1986). This fact can also be situational, as well as suggest an environment with good investment opportunities and, consequently, profitability.

The size of the company showed a significant and positive relationship with the FCF. The growth rate, on the other hand, presented a significant and negative relation with the FCF. From this standpoint, the found results corroborate the relationship initially expected in this study, being in accordance with the theory of Jensen and Meckling (1976) and Jensen (1986). Thus, the larger the size of the companies, the greater their FCFs. On the other hand, companies still in the growth phase, which have not reached maturity, tend to have a lower FCF.

In summary, the main findings of the research suggest that, among the corporate attributes discussed by Jensen and Meckling (1976), Jensen (1986) and Dylewski (2010), as possible determinants of the level of FCF, only the level of Corporate Governance 1 does not seem to influence it, except for the limitations of the study, in particular the deficiencies of the operational definitions of the variables and a possible selection bias introduced by the sampling criteria. And the other attributes - Corporate Governance Level 2 and Novo Mercado, size, return on investment, and growth rate - are explanatory factors for the FCF level.

These results contribute to the extent that they elucidate, in an environment subject to imperfections, how agents are acting and how this agency relationship is taking place, providing subsidies for a better understanding of how Corporate Governance mechanisms relate to the theory of FCFs. Furthermore, it fosters the debate for new research in the academic environment, providing the opportunity to broaden the discussion to the various stakeholders, given that the non-confirmation of the expected relationship raises a question about the advancement of this study in relation to the body of knowledge in the area.

As for the limitations of this research, it is worth pointing out that the found results are limited to the studied sample, due to the non-probabilistic characteristic of the sampling process. Thus, we emphasize that the interpretation of the results must be based on these limiting points, with the intent of not generalizing them to the entire population, but rather making them a critical guide in the decision-making process.

It is suggested, in order to consolidate the theory of FCFs, that future researches include other variables not considered in this study and that have the potential to support the mentioned theory, which will allow the continuity of this investigation. Additionally, other exogenous variables (stock prices, trading volume and macroeconomic variables, for example) could be employed in the study.

\section{REFERENCES}

Arruda, G. S., Madruga, S. R., \& Freitas Junior, N. I. (2008). A governança corporativa e a teoria da agência em consonância com a controladoria. Revista de Administração da UFSM, 1(1), 71-84.

Avelar, E. A., Cunha, N. G., Boina, T. M., \& Souza, A. A. (2015). Teoria dos Fluxos de Caixa Livres: uma Análise no Mercado Acionário Brasileiro. Anais Congresso USP de Controladoria e Contabilidade, São Paulo, SP, 15.

Baltagi, B. H. (2005). Econometric analysis of panel data (3a ed.). New York: John Wiley \& Sons. 
Brasil, Bolsa, Balcão, ([B] $\left.]^{3}\right)$ (2019). Segmentos de listagem. Retrieved on November 28, 2019, from http://www.b3.com.br/pt_br/produtos-e-servicos/solucoes-para-emissores/segmentos-delistagem/bovespa-mais/

Chi, J. D., \& Lee, D. S. (2010). The conditional nature of the value of corporate governance. Journal of Banking and Finance, 34(2), 350-361.

Dittmar, A., \& Mahrt-Smith, J. (2007). Corporate governance and the value of cash holdings. Journal of financial economics, 83(3), 599-634.

Dylewski, C. (2010). Determinantes do nível de caixa das empresas: análise de amostra de países da América Latina. Dissertação (Mestrado Profissional em Finanças e Economia), Fundação Getúlio Vargas, São Paulo, Brasil.

Fávero, L. P. L., Belfiore, P., Silva, F. L., \& Chan, B. L. (2009). Análise de Dados: Modelagem Multivariada para Tomada de Decisões. Rio de Janeiro: Elsevier.

Ferreira, C. O., Ferreira, P. O., Lamounier, W. M., \& Avelar, E. A. (2021). Fluxos de caixa livres e endividamento em operadoras de planos de saúde. ForScience, 9(1), e00865.

Ferreira, M. A., \& Vilela, A. S. (2004). Why do firms hold cash? Evidence from EMU countries. European Financial Management, 10(2), 295-319.

Francis, B., Hasan, I., Song, L., \& Waisman, M. (2013). Corporate governance and investmentcash flow sensitivity: Evidence from emerging markets. Emerging Markets Review, 15, 5771. http://doi.org/10.1016/j.ememar.2012.08.002

Gelbecke, E. R., Santos, A., Iudícibus, S., \& Martins, E. (2018). Manual de contabilidade societária: aplicável a todas as sociedades de acordo com as normas internacionais e do CPC. (3a ed.). São Paulo: Atlas.

Gujarati, D. N., \& Porter, D. C. (2011) Econometria Básica (5a ed.). Porto Alegre: AMGH Editora Ltda.

Gujarati, D.N. (2006). Econometria Básica. Rio de Janeiro: Elsevier.

Gupta, G., Mahakud, J., \& Verma, V. (2021), CEO's education and investment-cash flow sensitivity: an empirical investigation. International Journal of Managerial Finance, 17(4), 589-618. https://doi.org/10.1108/IJMF-01-2020-0020

Hedlund, P. R., Zaluski, F. C., Siqueira, C. S., Silva, P. R., Brizolla, M. M. B., Gomes, C. M., \& Mueller, A. A. (2021). A Relação entre Governança Corporativa e Teoria da Agência no Gerenciamento de Conflitos. Gestão e Sociedade, 15(41), 4144-4162.

Huu Nguyen, A., Thuy Doan, D., \& Ha Nguyen, L. (2020). Corporate governance and agency cost: Empirical evidence from Vietnam. Journal of Risk and Financial Management, 13(5), 103. 
Instituto Brasileiro de Governança Corporativa - IBGC (2019). Governança Corporativa. Retrieved from https://www.ibgc.org.br/conhecimento/governanca-corporativa.

Jensen, M. C. (1986). Agency Costs of Free Cash Flow, Corporate Finance, and Takeovers. American Economic Review, 76(2), 323-329.

Jensen, M. C., \& Meckling, W. H. (1976). Theory of the firm: managerial behavior, agency cost and ownership, structure. Journal of Financial Economics, 3, 305-360.

Johnston, J., \& DiNardo, J. (2001). Métodos econométricos (4a Ed.). Portugal: Mcgraw-Hill.

Keynes, J. M. (1936). The general theory of employment, interest, and money. Springer.

Klann, R. C., Gomes, E. C. O., Greuel, M. A., \& Bezerra, F. A. (2014). Influência do Risco Moral e da Accountability nas tomadas de decisões. Contabilidade Vista \& Revista, 25(1), 99118.

Lambright, K. T. (2009). Agency theory and beyond: Contracted providers' motivations to properly use service monitoring tools. Journal of Public Administration Research and Theory, 19, 207-227.

Lang, L. H. P., Stulz, R. M., \& Walkling, R. A. (1991). A test of the free cash flow hypothesis. Journal of Financial Economics, 29, 315-335.

Lerner, A. F. (2019). Relação do fluxo de caixa livre com o desempenho econômico e os custos de agência. Dissertação (Mestrado em Ciencias Econômicas), UFRGS, Porto Alegre, RS, Brasil.

Lerner, A. F., \& Victor, F. G. (2020). Análise da Influência do Fluxo de Caixa Livre nos Indicadores de Desempenho Econômico em Companhias Abertas Brasileiras. Navus: Revista de Gestão e Tecnologia, 10(1), 1-23.

Li, M., \& Song, L. (2018). Corporate governance, accounting information environment and investment-cash flow sensitivity. International Journal of Accounting \& Information Management, 26(4), 492-507. https://doi.org/10.1108/IJAIM-04-2017-0049

Lodi, J. B. (2000). Governança Corporativa. Rio de Janeiro: Campus.

Machado, J. H., \& Galdi, F. C. (2021). Ativos Intangíveis e Estrutura de Propriedade: Evidências no Mercado Brasileiro. Anais do USP International Conference in Accounting, São Paulo, SP, Brasil, 21.

Macho-Stadler, I., \& Pérez-Castrillo, J. D. (2001). An introduction to the economics of information: incentives and contracts. Oxford University Press on Demand.

Martin, N. C., Santos, L. R., \& Dias Filho, J. M. (2004). Governança Empresarial, Riscos e Controles Internos: A Emergência de um Novo Modelo de Controladoria. Revista Contabilidade \& Finanças, 34(1), 7-22. 
McKnight, P. J., \& Weir, C. (2009). Agency costs, corporate governance mechanisms and ownership structure in large UK publicly quoted companies: A panel data analysis. The Quarterly Review of Economics and Finance, 49(2),139-58.

Modigliani, F., \& Miller, M. H. (1958). The cost of capital, corporation finance and the theory of investment. The American, $1,3$.

Oliveira, F. B., \& Fontes Filho, J. R. (2021). Mudanças nas configurações de governança corporativa e relações de agência: uma análise longitudinal em empresa de capital fechado. Cadernos EBAPE, 19, 510-523.

Raupp, F. M., \& Beuren, I. M. (2008). Metodologia da pesquisa aplicável às ciências sociais. In I. M. Beuren (Org.). Como elaborar trabalhos monográficos em Contabilidade: teoria e prática. São Paulo: Atlas.

Sehrawat, N. K., Kumar, A., Lohia, N., Bansal, S., \& Agarwal, T. (2019). Impact of Corporate Governance on Earnings Management: Large Sample Evidence from India. Asian Economic and Financial Review, 9(12), 1335.

Shleifer, A., \& Vishny, R.W. (1997). A Survey of Corporate Governance. The Journal of Finance. Retrieved on November 27, 2019, from https://scholar.harvard.edu/files/shleifer/files/surveycorpgov.pdf

Silva, B. A. O., Caixe, D. F., \& Krauter, E. (2019). Governança Corporativa e Sensibilidade Investimento-Fluxo de Caixa no Brasil. Revista Brasileira de Finanças, 17(2), 72-86.

Sprenger, C., \& Lazareva, O. (2021). Corporate governance and investment-cash flow sensitivity: Evidence from Russian unlisted firms. Journal of Comparative Economics, 49(3), september. https://doi.org/10.1016/j.jce.2021.05.004

Waly, N. A., Sasongko, N., \& Achyani, F. (2021). Effect of Free Cash Flow, Enterprise Risk Management Disclosure and Sustainability Report on Company Value With Corporate Governance as Moderating Variable. SENTRALISASI, 10(2), 140-146.

Wang, G. Y. (2010). The impacts of free cash flows and agency costs on firm performance. Journal of Service Science and Management, 3(Dec), 408-418.

Yeo, H. J. (2018). Role of free cash flows in making investment and dividend decisions: The case of the shipping industry. The Asian Journal of Shipping and Logistics, 34(2), 113-118.

Zhang, X. (2020). Corporate Governance and Agency Costs of Free Cash Flow in Acquisitions (Doctoral dissertation), Concordia University. 